\title{
Food Safety Regulatory Agencies and Steps to Opening a Food Business in Florida ${ }^{1}$
}

\author{
Matthew D. Krug, Jennifer Hagen, and Sarah M. Ellis²
}

This document is one in a "Florida Food Entrepreneur" series, which seeks to assist new and established food entrepreneurs by providing information on topics relevant to food-based businesses.

\section{Background}

In Florida, three main agencies enforce food safety regulations and license food businesses: (1) the Florida Department of Business and Professional Regulation (DBPR), (2) the Florida Department of Agriculture and Consumer Services (FDACS), and (3) the Florida Department of Health (DOH). Each agency enforces regulations pertaining to a different sector of food businesses. With three agencies enforcing similar rules, food entrepreneurs often struggle to find the correct information needed to obtain a license to open a food business. This publication intends to introduce food entrepreneurs to the various agencies in Florida that regulate food businesses and provide a brief overview of the steps to open a food business in Florida.

\section{What does each agency regulate? Florida Department of Business and Professional Regulation (DBPR)}

DBPR regulates food service establishments that prepare and serve food to the public, including restaurants, caterers, most mobile food vendors, hotdog carts, and temporary events such as festivals. All licensees are required to successfully pass a safety and sanitation inspection prior to opening. Additionally, food establishments are subject to inspection as often as necessary to protect public health, safety, and welfare.

\section{Florida Department of Agriculture and Consumer Services (FDACS)}

FDACS regulates commercial food establishments that manufacture, process, pack, hold, and prepare food for sale or distribution or sell food directly to customers. Establishments regulated by FDACS include retail food establishments such as convenience stores and grocery stores, wholesale and retail food processing operations, storage and warehouse operations, and nonalcoholic beverage operations such as coffee shops. Additionally, FDACS regulates food establishments that sell only prepackaged or non-potentially hazardous foods. FDACS inspects food operations routinely to ensure consumer safety.

\section{Florida Department of Health (DOH)}

$\mathrm{DOH}$ regulates institutional food service establishments such as schools, detention facilities, and assisted-living facilities. They also regulate civic and fraternal organizations, bars and lounges that do not prepare food, and theaters with limited food service such as popcorn and soda. DOH inspects facilities based on risk to public health.

1. This publication is FSHN22-2, one of a series of the Food Science and Human Nutrition Department, UF/IFAS Extension. Original publication date February 2022. Visit the EDIS website at https://edis.ifas.ufl.edu/ for the currently supported version of this publication.

2. Matthew D. Krug, state specialized Extension agent II, Food Science and Human Nutrition Department, UF/IFAS Southwest Florida Research and Education Center; Jennifer Hagen, family and consumer sciences agent I, UF/IFAS Extension Lee County; and Sarah M. Ellis, family and consumer sciences agent II, UF/IFAS Extension Citrus County; UF/IFAS Extension, Gainesville, FL 32611.

The Institute of Food and Agricultural Sciences (IFAS) is an Equal Opportunity Institution authorized to provide research, educational information and other services

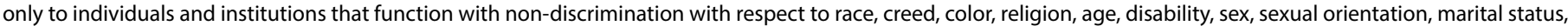

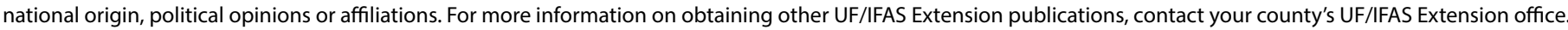
U.S. Department of Agriculture, UF/IFAS Extension Service, University of Florida, IFAS, Florida A \& M University Cooperative Extension Program, and Boards of County Commissioners Cooperating. Andra Johnson, dean for UF/IFAS Extension. 
Risk factors include the type of food, the population served, the preparation required, and the quantity of food prepared. Facilities at high risk are inspected quarterly, while low-risk facilities are inspected annually.

\section{Other Food Regulatory Agencies}

In addition to the three main food regulatory agencies in Florida, the following agencies regulate food services for some of their licensed facilities:

- The Florida Department of Children and Families regulates food services for childcare facilities or agencies that care for children.

- The Florida Department of Elder Affairs regulates food services for congregant dining sites and home-delivered meals.

- The Agency for Persons with Disabilities regulates food services for group homes that provide services for persons with disabilities.

- The Agency for Health Care Administration regulates food services for hospitals and nursing homes.

\section{Steps to Opening a Food Business in Florida}

\section{- Business Registration}

Food entrepreneurs must register their business with the Florida Department of State, Division of Corporations. Information on how to form a business and register can be found on the Florida Department of State, Division of Corporations website: www.sunbiz.org.

\section{- Tax Registration}

New food businesses will need to register with the Internal Revenue Service (IRS) and obtain an Employer Identification Number (EIN). Information on how to register with the IRS and obtain an EIN can be found on the IRS website: https://www.irs.gov. Additionally, businesses need to register with the Florida Department of Revenue to obtain a Florida Tax ID. Information on how to register can be found on the Florida Department of Revenues website: https://floridarevenue.com. Businesses should also check with their local tax collector (county and city if applicable) to determine if they must also obtain a county or city business tax prior to opening.
- Food Safety Regulations, Training, and Licensing

\section{- Regulations:}

The state regulatory authorities have adopted and are enforcing specific regulations on the licensees. A common example is the FDA Food Code, which is usually required for all DBPR- and DOH-regulated businesses and some FDACS-regulated businesses. All wholesale/manufactured food businesses are required to follow the federal Current Good Manufacturing Practices (CGMPs) found in 21 CFR 117 and are required to follow additional regulations for products such as acidified foods (e.g., salsa), juice, or seafood. Furthermore, wholesale/manufactured food businesses with gross annual sales above $\$ 1,000,000$ are subject to the Preventive Control for Human Food Rule. To learn more, visit https://www.fdacs. gov/Business-Services/Food/Food-Establishments/ Wholesale-Manufactured-Food-Program.

Retail food businesses working with a product that requires a special process to be approved by FDACS may be required to create and submit a Hazard Analysis and Critical Control Point (HACCP) food safety plan. To learn more, visit https://www.fdacs. gov/Business-Services/Food/Food-Establishments/ Retail-Food-Program/Special-Processes-at-Retail.

Additionally, wholesale/manufactured food businesses may be required to label their food products. The Food and Drug Administration (FDA) is responsible for assuring foods sold in the United States are properly labeled. Food labeling guidance documents can be found at https://www.fda.gov/regulatory-information/search-fda-guidance-documents/ guidance-industry-food-labeling-guide.

\section{- Training:}

Food managers working for businesses subject to the FDA Food Code must complete food service manager training and successfully pass the exam. There are several accredited programs that can be completed to meet this requirement, including the ServSafe program (https://www.servsafe.com).

Other trainings/certifications may be required for food business owners, managers, or employees depending on which regulation applies to the business. Check with the regulatory agency to see what trainings are required. 


\section{- Licensing:}

Licensing from the appropriate agency is required prior to operation. See the "Steps to Obtaining a Food Establishment License" section for more information.

\section{Steps to Obtaining a Food Establishment License}

\section{Plan review and approval}

DBPR, FDACS, and DOH have plan review options where facility plans can be submitted prior to construction or opening and reviewed by agency personnel to ensure the establishment meets the minimum standards. If the facility is newly built, converted, remodeled, or reopened after being closed for one year or more, a plan review may be required.

A plan review may not be required if a facility is already licensed and no changes are made to the layout. Food entrepreneurs should confirm the need for a plan review with the appropriate agency before submitting. While a plan review may not be required, food business owners or managers may wish to have one conducted. A plan review can ensure the food business complies with current sanitation and safety requirements.

\section{Complete application}

To apply for a license, each regulatory authority requires operators of food service establishments to submit a completed application, including any additional forms. Links to licensing information from each agency are found in the "Resources" section.

\section{Submit application and fees}

The completed application and fees are sent to the appropriate regulatory authority. Both DBPR and FDACS accept applications online or by mail. DOH accepts applications at the County Health Department office.

\section{Inspection}

Before opening, all new food service establishments must pass a sanitation and safety inspection. Once the application and required documentation have been received, an inspector should contact the applicant to schedule an inspection. If the applicant is not contacted by an inspector within two weeks, contact the regulatory authority.

\section{License Renewal}

Licenses are renewed on an annual basis. The food service establishment is responsible for ensuring its license is renewed each year. Establishments that fail to renew by the expiration date are considered to be operating without a valid license and may be subject to fines or adverse actions by the regulatory authority. Furthermore, each regulatory authority may assess a late fee if the license is renewed after the expiration date.

\section{Resources}

For more information or to apply for a food license, see the resources below:

DBPR: https://www.myfloridalicense.com/intentions2.asp?c hBoard=true $\&$ SID $=\&$ boardid $=200$

FDACS: https://www.fdacs.gov/Business-Services/Food/ Food-Establishments

DOH: http://www.floridahealth.gov/environmental-health/ food-safety-and-sanitation/index.html

Plan Review application links:

DBPR: http://www.myfloridalicense.com/dbpr/hr/forms/ documents/application_packet_for_plan_review.pdf

FDACS: http://forms.fdacs.gov/14222.pdf

DOH: http://www.floridahealth.gov/environmental-health/ food-safety-and-sanitation/_documents/PlanReviewGuide. pdf 